\title{
Association of CYP2C19*2 polymorphism with clopidogrel resistance among patients with high cardiovascular risk in Northeastern Mexico
}

\section{Asociación del polimorfismo CYP2C19*2 con resistencia a clopidogrel en pacientes con alto riesgo cardiovascular en el noreste de México}

\begin{abstract}
Félix R. Cedillo-Salazar', Lizeth Martínez-Jacobo*, Yadira X. Pérez-Páramo ${ }^{3}$, Ricardo Cerda-Flores ${ }^{4}$, Laura E. Martínez ${ }^{5}$, José C. Jaime-Pérez ${ }^{6}$, María G. Moreno-Treviño², Edelmiro Pérez-Rodríguez Francisco J. Bosques-Padilla ${ }^{8}$, Montserrat Cedillo-Avila ${ }^{1}$, María A. Cedillo-Avila ${ }^{9}$ y Michelle Zamudio-Osuna ${ }^{5}$

${ }^{1}$ Cardiology Service, Hospital Universitario "Dr. José Eleuterio González", Faculty of Medicine, Universidad Autónoma de Nuevo León, Monterrey; ${ }^{2}$ Department of Basic Sciences, Vice-Rectory of Health Sciences, Universidad de Monterrey, San Pedro Garza García, Nuevo León, Mexico; ${ }^{3}$ College of Pharmacy and Pharmaceutical Sciences, Washington State University, Spokane, Washington, USA; ${ }^{4}$ Faculty of Nursing; ${ }^{5}$ Department of Genetics; ${ }^{6}$ Hematology Service; ${ }^{7}$ General Surgery Service, Hospital Universitario "Dr. José Eleuterio González"; ${ }^{8}$ Department of Internal Medicine. Faculty of Medicine, Universidad Autónoma de Nuevo León; ${ }^{9}$ Escuela de Medicina, Universidad Del Valle de México, Monterrey, Nuevo León, Mexico
\end{abstract}

\begin{abstract}
Objective: Oral antiplatelet drugs are a key to modern pharmacotherapy in cardiovascular atherothrombotic diseases. Clopidogrel (CLO) constitutes the main preventive treatment of atherothrombosis. However, a considerable inter-individual variation in CLO response has been documented, resulting in suboptimal therapy and an increased risk of recurrent adverse effects in some patients. The enzyme CYP2C19 has been reported to be the CYP isoform that activates CLO to its active metabolite. Several single nucleotide polymorphisms in the CYP2C19 gene have been identified as strong predictors of CLO-impaired pharmacological response. At least 16 variants have been associated with changes in CYP2C19 activity. Materials and Methods: The following research was composed of a total of 102 subjects with high cardiovascular risk in the northeast of Mexico, with a maintenance dose of $75 \mathrm{mg}$ of CLO per day. The platelet reactivity was measured with VerifyNow P2Y12 assay, while the presence of CYP2C19*2 was identified by real-time polymerase chain reaction. Results: Patients were categorized by CYP2C19 metabolizer status based on *2 genotypes using the common consensus star allele nomenclature as normal metabolizer (G/G), intermediate metabolizer $(G / A)$, and poor metabolizer $(A / A)$, respectively. The phenotype frequency for CYP2C19² was $74.5 \%(G / G), 21.6 \%(G / A)$, and $3.9 \%(A / A)$. The subjects with the $A$ allele presented
\end{abstract}

\footnotetext{
Correspondencia:

*Lizeth Martínez Jacobo Department of Basic Sciences

Vice-Rectory of Health Sciences Universidad de Monterrey Av. Morones Prieto, 4500

Fecha de recepción: 17-01-2019 Fecha de aceptación: 03-06-2019 C.P. 66238, San Pedro Garza García, N.L., México E-mail: lizeth.martinezj@udem.edu DOI: 10.24875/ACM.19000033

Disponible en internet: 05-08-2019 Arch Cardiol Mex. 2019;89(4):324-329 www.archivoscardiologia.com 1405-9940/@ 2019 Instituto Nacional de Cardiología Ignacio Chávez. Publicado por Permanyer. Este es un artículo open access bajo la licencia CC BY-NC-ND (http://creativecommons.org/licenses/by-nc-nd/4.0/)
} 
$\geq 235$ P2Y12 reaction unit levels, classifying them how poor metabolizer. The prevalence of reduced CLO effectiveness was associated with the presence of CYP2C19*2 polymorphism among Mexican patients. Conclusion: The presence of the CYP2C19*2 allele is related to resistance to the antiplatelet effect of $\operatorname{CLO}(p=0.003)$.

Key words: CYP2C19*2. Clopidogrel. High cardiovascular risk. Polymorphism. Resistance. Allele.

\section{Resumen}

Objetivo: Los antiplaquetarios orales son clave en la farmacoterapia moderna de las enfermedades aterotrombóticas cardiovasculares. Clopidogrel (CLO) constituye el principal tratamiento preventivo de aterotrombosis (AT). Sin embargo, se ha documentado una considerable variación interindividual en la respuesta a CLO, lo que da como resultado una terapia subóptima y mayor riesgo de efectos adversos en algunos pacientes. La enzima CYP2C19 es la isoforma CYP que activa CLO a su metabolito activo. Se han identificado varios polimorfismos de un solo nucleótido en el gen CYP2C19 como fuertes predictores de respuesta farmacológica alterada a CLO. Al menos 16 variantes se han asociado con cambios en la actividad de CYP2C19. Método: Se reclutaron un total de 102 sujetos con alto riesgo cardiovascular del noreste de México, con dosis de mantenimiento de $75 \mathrm{mg}$ de CLO/día. La reactividad plaquetaria se midió con el ensayo Verify Now P2Y12, la presencia de CYP2C19*2 se identificó mediante polymerase chain reaction en tiempo real. Resultado: Los pacientes fueron clasificados por el estado metabolizador CYP2C19*2 utilizando nomenclatura consenso, como metabolizador normal (G/G), metabolizador intermedio $(G / A)$ y metabolizador pobre $(A / A)$, respectivamente. La frecuencia del fenotipo para CYP2C19*2 fue $74.5 \%$ $(G / G), 21.6 \%(G / A)$ y $3.9 \%(A / A)$. Los sujetos con alelo A presentaron $\geq 235$ niveles P2Y12 reaction unit, clasificándolos como metabolizadores deficientes. La prevalencia de eficacia reducida a CLO se asoció con la presencia del polimorfismo CYP2C19*2 en pacientes mexicanos. Conclusiones: La presencia del alelo CYP2C19*2 se relaciona con resistencia al efecto antiagregante plaquetario del CLO $(p=0.003)$.

Palabras clave: CYP2C19*2. Clopidogrel. Alto riesgo cardiovascular. Polimorfismo. Resistencia. Alelo.

\section{Introduction}

Atherothrombosis (AT), the leading cause of mortality in the Western world, is defined as an atherosclerotic plaque disruption with superimposed thrombosis ${ }^{1}$. AT is the main cause of ischemic heart disease, ischemic stroke, and peripheral arterial disease ${ }^{2}$. AT may also occur in patients with arrhythmias, such as atrial fibrillation, and in those who have undergone percutaneous or surgical revascularization procedures.

Human platelets are involved in normal and pathological hemostasis. During the AT process, platelets act as essential mediators of several thrombotic and inflammatory events. Clopidogrel (CLO), an antiplatelet drug, inhibits the P2Y12 receptor, which is responsible for mediating the platelet aggregation by adenosine diphosphate ${ }^{3}$.

Inhibition of platelet aggregation with drugs such as CLO and acetylsalicylic acid constitutes the main preventive treatment of AT. CLO is one of the most commonly used therapeutic drugs for the secondary prevention of cardiovascular events in patients with acute coronary syndromes ${ }^{4}$. However, considerable inter-individual variation in CLO response has been documented, resulting in suboptimal therapy and an increased risk of recurrent adverse effects in some patients 5 .
CLO is a prodrug that requires conversion to an active metabolite by hepatic cytochromes p450 (CYP) to accomplish an antiplatelet effect. The enzyme CYP2C19 has been reported to be the CYP isoform that activates CLO to its active metabolite 6 . Several single nucleotide polymorphisms (SNPs) in the CYP2C19 gene (OMIM124020) have been identified as strong predictors of CLO-diminished pharmacological response $^{4}$. Furthermore, a non-satisfactory effect has been observed in $20 \%$ of patients with $\mathrm{CLO}^{7}$. CYP2C19 is a liver enzyme that metabolizes a broad range of xenobiotics with clinical importance, such as benzodiazepines, antidepressants, mephenytoin, some proton pump inhibitors, and CLO .

It has been demonstrated that genetic variants in the CYP2C19 gene affect the pharmacological and clinical response to the standard $75 \mathrm{mg}$ daily maintenance dose of CLO. Furthermore, at least 16 variants have been associated with changes in CYP2C19 enzymatic activity and seven specific variants result in an inactive enzyme. CYP2C19*1 is the wild-type allele, while CYP2C19*2 (rs4244285) is the null allele (rs4244285; 681G>A) and CYP2C19*3 (rs4986893; $636 \mathrm{G}>\mathrm{A}$ ) results in an inactive enzyme ${ }^{9}$. Recently, the loss-of-function CYP2C19*2 allele has been associated 
with decreased activation of CLO, poor antiaggregant effect, and increased cardiovascular events ${ }^{10}$. In highrisk vascular patients, the CYP2C19*2 polymorphism is a strong predictor of adverse cardiovascular events and particularly of stent thrombosis ${ }^{10}$.

\section{Aim}

The aim is to determine the prevalence of resistance to the antiplatelet effect of CLO and its relationship with the presence of the genetic polymorphism CYP2C19*2 (rs4244285), in a population of Mexican patients with high cardiovascular risk in the northeast of Mexico.

\section{Materials and Methods}

\section{Study population}

A total of 102 patients from Northeastern Mexico diagnosed with high risk of cardiovascular disease who attended the Cardiology Service of the Hospital Universitario "Dr. José Eleuterio González" (UANL) and the "Institute for Cardiac Arrhythmias and Cardiovascular Diagnosis, S. C." of Monterrey, Mexico, were included. The individuals were recruited from January to August 2015, with a mean age of 68 (35-91) years. The inclusion criteria were as follows: males and females over 18 years, diagnosed with high risk of cardiovascular disease, and who have received treatment with CLO at a maintenance dose of at least $75 \mathrm{mg}$ daily during the last nine consecutive days before the inclusion to the study. Exclusion criteria were the following: pregnant women, people who are taking prasugrel or ticlopidine, people who are taking proton pump inhibitors, or people who have stopped treatment with proton pump inhibitors for 1-7 days before starting treatment with CLO and history of CLO allergy (Fig. 1). This study was approved by the Ethics Committee of UANL" and registered under the resolution number C414-004. Informed consent was obtained from all patients.

\section{Genotyping}

Blood samples were collected in tubes containing EDTA, and DNA was extracted using Wizard ${ }^{\circledR}$ Genomic DNA Purification Kit (Promega, Madison, WI, USA). DNA quality was assessed according to standard spectrophotometrically procedures using a NanoDrop spectrophotometer (Thermo Fisher Scientific, Waltham, MA, USA). Genomic DNA was genotyped for the

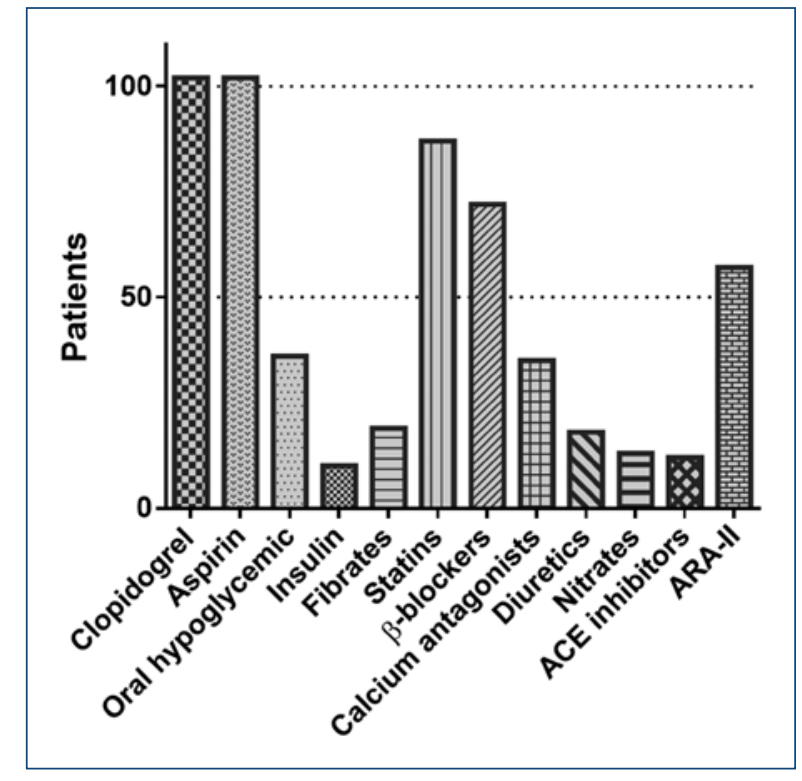

Figure 1. Medications used by the study population. ACE: angiotensin-converting enzyme; ARA-II: angiotensin II receptor antagonists.

polymorphism CYP2C19*2 (681G>A, dbSNP rs4244285) using real-time polymerase chain reaction (PCR) (quantitative polymerase chain reaction [qPCR]) and Taqman ${ }^{\circledR}$ probes (Applied Biosystems; Thermo Fisher Scientific, Inc., HS) according to the manufacturer's protocol. StepOne System (Applied Biosystems; Thermo Fisher Scientific, Inc.) was used to perform the real-time PCR, and data were analyzed in the SPSS v20 software (IBM Corp., Armonk, NY, USA). The call rate was $>99 \%$ in the qPCR experiment.

\section{Platelet aggregometry}

P2Y12 reaction unit (PRU) levels were measured utilizing the VerifyNow P2Y12 assay (Accumetrics, San Diego, CA, USA). This method was used to assay patient's platelet reactivity to antiplatelet medication with CLO. Platelet antiaggregation was determined after a maintenance dose of at least $75 \mathrm{mg} /$ day for a period of not $<9$ days.

\section{Statistics}

Kolmogorov-Smirnov test was used to determine the distribution of the numerical variables (normal or not normal), and a parametric test was performed with Student's $t$-test for comparison of means. The level of significance was established at a value of $p<0.05$. 
Table 1. Population characteristics

\begin{tabular}{|l|c|}
\hline Characteristics $\mathbf{( n = 1 0 2 )}$ & $\mathbf{n}(\%)$ \\
\hline Male & $64(62.7)$ \\
\hline Female & $38(37.3)$ \\
\hline Age mean (range) & $68(35-91)$ \\
\hline Obesity & $30(29.4)$ \\
\hline Smokers & $29(28.4)$ \\
\hline Dyslipidemia & $55(53.9)$ \\
\hline Hypertension & $59(57.8)$ \\
\hline Diabetes mellitus & $36(35.3)$ \\
\hline Acute myocardial infarction & $28(27.4)$ \\
\hline Unstable angina & $10(9.8)$ \\
\hline Stable angina & $42(41.1)$ \\
\hline Transient ischemic attack & $5(4.9)$ \\
\hline Supraventricular tachycardia & $11(10.7)$ \\
\hline Neurocardiogenic syncope & $8(7.8)$ \\
\hline Heart block & $4(3.9)$ \\
\hline X syndrome & $3(2.9)$ \\
\hline Hypothyroidism & $5(4.9)$ \\
\hline Prostatic hyperplasia & $5(4.9)$ \\
\hline Dyspepsia & $11(10.7)$ \\
\hline Cancer & $4(3.9)$ \\
\hline sample size; $\%$ percentage. & \\
\hline
\end{tabular}

Table 2. CYP2C19*2 frequency

\begin{tabular}{|l|l|c|}
\hline Allele & Phenotype & Frequency n (\%) \\
\hline GG & Normal & $76(74.5)$ \\
\hline GA & Intermediate & $22(21.6)$ \\
\hline AA & Poor & $4(3.9)$ \\
\hline
\end{tabular}

n: sample size; \%: percentage.

Analysis was conducted using the Statistical Package SPSS v20 Software (IBM Corp., Armonk, NY, USA) and GraphPad Prism v6.0 (La Jolla, CA, USA).

\section{Results}

One hundred and two patients were included in the study and their demographic characteristics are summarized in Table 1. The mean age was 68 years, and $62.7 \%$ were male; the risk factors among our population were: $57.8 \%$ showed hypertension, $35.3 \%$ showed diabetes mellitus, and $53.9 \%$ showed dyslipidemias at the sample collection moment.

\section{Genotype}

A total of 102 patients from Northeast Mexico diagnosed with high risk of cardiovascular disease were genotyped for CYP2C19*2 (681G>A, dbSNP rs4244285). The genotype frequencies obtained were $74.5 \%(\mathrm{G} / \mathrm{G})$, $21.6 \%(G / A)$, and $3.9 \%(A / A)$. Patients were categorized by CYP2C19 metabolizer status based on *2 genotypes using the common consensus star allele nomenclature as normal metabolizer $(G / G)$, intermediate metabolizer $(G / A)$, and poor metabolizer $(A / A)$, respectively (Table 2) $)^{8}$.

\section{CLO response}

According to the aggregometry results, the patients were classified into three groups. Group 1: 47 patients (46\%) were classified as good responders, with a PRU level $\leq 194$ evidencing a $>40 \%$ block of the P2Y12 receptor; Group 2: 28 patients (27.5\%) with a PRU level of $194-235$ (20 to $40 \%$ of P2Y12 receptor blocking), classified as intermedium responders; and Group 3: 27 patients (26.5\%) with $\geq 235$ PRU $<20 \%$ of $\mathrm{P} 2 \mathrm{Y} 12$ receptor blocking) as poor responders.

\section{Genotype/phenotype}

Most of the patients with PRU levels $<235$ presented the G/G homozygous genotype for the CYP2C19*1 wild-type isoform. In contrast, patients who presented $\geq 235$ PRU levels presented the SNP CYP2C19*2 in at least one allele $(G / A$ or $A / A)$. This finding denotes that CYP2C19-reduced enzymatic function shows a significant difference $(p=0.003)$ when compared to the enzymatic activity of CYP2C19 wild-type isoform in CLO activation (Fig. 2).

\section{Discussion}

CLO has very special and complex pharmacodynamic characteristics, including first pass hepatic metabolism, variation in absorption, drug-drug metabolism, and SNPs in the enzymes responsible for CLO metabolism. As a result, a very variable and unpredictable inter-individual response to this therapy is observed 


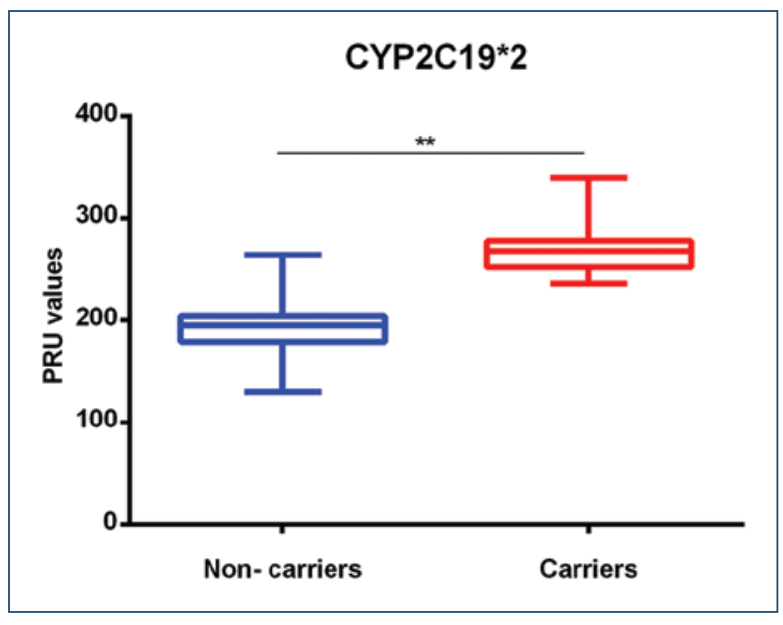

Figure 2. Relationship between the presence of the reduced function allele and platelet antiaggregation $\left.{ }^{* *} \mathrm{p}=0.003\right)$. PRU (P2Y12 reaction units), non-carriers $(G / G /)$, carriers (G/A, A/A). Error bars: $95 \% \mathrm{Cl}$ (confidence interval).

favoring the treatment failure. The estimated resistance to CLO fluctuates between 4 and $30 \%{ }^{11}$. In our specific population, the biomarkers necessary for the measurement of resistance to this therapy have not been explored.

This study describes the CYP2C19*2 $(681 \mathrm{G}>\mathrm{A})$ presence in a group of patients with high cardiovascular risk from the northeast area of Mexico with genotype frequency of $74.5 \%$ for $G / G, 21.6 \%$ for $G / A$, and $3.9 \%$ for A/A. The allele CYP2C19*2 was present in $25.5 \%$ of the patients, with a $3.9 \%$ of homozygous genotype among patients. This finding is in agreement with a previous study performed in a sample of 51 Mexican mestizo patients from the central region of Mexico with a $17 \%$ genetic frequency and $3.9 \%$ of the patients having $A / A$ in a homozygous fashion ${ }^{12}$.

CYP2C $19 * 2$ accounts for $75-85 \%$ of the alleles responsible for the poor metabolizer phenotype in Caucasians and East Asians ${ }^{13}$. This allele is significantly more frequent in East Asian populations (14-39\%) than among Caucasians (8-16\%) and Africans (18-25\%) However, in Koreans, the frequency of CYP2C19*2 is reported to be $28 \%$, similar to $27 \%$ in the Japanese population, but showing a large difference from the Chinese population ${ }^{13}$. CYP2C19*2 transmission pattern has been observed how an autosomal recessive and autosomal codominant traits ${ }^{14,15}$.

According to the results of the aggregometry, $46 \%$ of the patients were classified as good responders,
$27.5 \%$ showed of $20-40 \%$ of the P2Y12 blocking effect, and $26.5 \%$ were classified as poor responders. This observation agrees with the reported by Viveros et al., 2016, where $40 \%$ of the patients were good responders while $60 \%$ of the patients were non-responders ${ }^{12}$. Most of the patients $(98.6 \%)$ with the G/G genotype presented PRU levels $<234$ were classified as responders. In contrast, carriers of at least one $A$ allele $(G / A$ and $A / A)$ showed a $P R U \geq$ 235 indicating $<20 \%$ blocking effect of the P2Y12 and were classified as resistant or non-responder patients. Discrepancies in response to drugs are partially due to polymorphisms in genes involved in drug metabolism and transport. Furthermore, it has been shown that the frequency, pattern, and impact of these polymorphisms vary among populations ${ }^{16,17}$.

The principal problem that physicians face when prescribing antiplatelet agents is the lack of a standardized method for the antiplatelet function. In addition, a cut-point for this function to provide a clear patient classification as responder or non-responder to CLO treatment has not been established ${ }^{18}$.

The resistance to CLO can be classified as clinical or laboratory-based resistance. Clinical resistance could be defined when a cardiovascular event happens in an individual who is currently receiving the antiplatelet treatment. Meanwhile, the laboratory-based resistance is defined as the in vitro failure of the platelet block activity of an individual who is currently under CLO treatment ${ }^{17}$.

Several laboratory methods have been proposed for the diagnosis of CLO antiplatelet resistance, yet all of them present advantages and disadvantages ${ }^{18}$. The big variability reported in the levels of resistance to CLO is due to the absence of a unified definition of the current laboratory tests and to the heterogeneity in the different study groups and protocols.

The results observed in this cohort reflect the importance of both the genotype game of CYP2C19 and the platelet aggregation test as an important predictor to the response and resistance to CLO in patients with high cardiovascular risk.

The prevalence of reduced CLO effectiveness is associated with the presence of $\mathrm{CYP} 2 \mathrm{C} 19^{*} 2$ polymorphism among patients. This finding denotes that $\mathrm{CY}$ P2C19-reduced enzymatic function show a significant difference $(p=0.003)$ when compared to the enzymatic activity of CYP2C19 wild-type isoform in CLO activation. 


\section{Funding}

The present investigation has not received specific grants from agencies of the public sector, commercial sector, or nonprofit entities.

\section{Conflicts of interests}

None.

\section{Ethical disclosures}

Protection of human and animal subjects. The authors declare that no experiments were performed on humans or animals for this study.

Confidentiality of data. The authors declare that they have followed the protocols of their work center on the publication of patient data.

Right to privacy and informed consent. The authors declare that no patient data appear in this article.

\section{References}

1. Viles-Gonzalez JF, Fuster V, Badimon JJ. Atherothrombosis: a widespread disease with unpredictable and life-threatening consequences. Eur Heart J. 2004;25:1197-207.

2. Herrington W, Lacey B, Sherliker P, Armitage J, Lewington S. Epidemiology of atherosclerosis and the potential to reduce the global burden of atherothrombotic disease. Circ Res. 2016;118:535-46.

3. Rytkin E, Mirzaev KB, Grishina EA, Smirnov VV, Ryzhikova KA, Sozaeva ZA, et al. Do CYP2C19 and ABCB1 gene polymorphisms and low CYP3A4 isoenzyme activity have an impact on stent implantation complications in acute coronary syndrome patients? Pharmgenomics Pers Med. 2017; 10:243-5.

4. Giusti B, Gori AM, Marcucci R, Saracini C, Vestrini A, Abbate R, et al. Determinants to optimize response to clopidogrel in acute coronary syndrome. Pharmgenomics Pers Med. 2010;3:33-50.
5. Backman JD, Yerges-Armstrong LM, Horenstein RB, Newcomer S, Shaub S, Morrisey M, et al. Prospective evaluation of genetic variation in platelet endothelial aggregation receptor 1 reveals aspirin-dependent effects on platelet aggregation pathways. Clin Transl Sci. 2017; 10:102-9.

6. Han SW, Kim YJ, Ahn SH, Seo WK, Yu S, Oh SH, et al. Effects of triflusal and clopidogrel on the secondary prevention of stroke based on cytochrome P450 2C19 genotyping. J Stroke. 2017;19:356-64.

7. Snoep JD, Hovens MM, Eikenboom JC, van der Bom JG, Jukema JW, Huisman MV, et al. Clopidogrel nonresponsiveness in patients undergoing percutaneous coronary intervention with stenting: a systematic review and meta-analysis. Am Heart J. 2007;154:221-31.

8. Scott SA, Sangkuhl K, Stein CM, Hulot JS, Mega JL, Roden DM, et al. Clinical pharmacogenetics implementation consortium guidelines for CYP2C19 genotype and clopidogrel therapy: 2013 update. Clin Pharmacol Ther. 2013;94:317-23.

9. Luo HR, Poland RE, Lin KM, Wan YJ. Genetic polymorphism of cytochrome P450 2C19 in Mexican Americans: a cross-ethnic comparative study. Clin Pharmacol Ther. 2006;80:33-40.

10. Wang Y, Zhao X, Lin J, Li H, Johnston SC, Lin Y, et al. Association between CYP2C19 loss-of-function allele status and efficacy of clopidogrel for risk reduction among patients with minor stroke or transient ischemic attack. JAMA. 2016;316:70-8.

11. Nguyen TA, Diodati JG, Pharand C. Resistance to clopidogrel: a review of the evidence. J Am Coll Cardiol. 2005;45:1157-64.

12. Viveros ME, Areán $C$, Gutiérrez $S$, Vázquez $S$, Cardiel MH, Taboada A, et al. Evaluation of clopidogrel response variability and identification of the CYP2C19 polymorphism in Mexican patients. Arch Cardiol Mex. 2016;86:297-304

13. Shin DJ, Kwon J, Park AR, Bae Y, Shin ES, Park S, et al. Association of CYP2C19*2 and *3 genetic variants with essential hypertension in Koreans. Yonsei Med J. 2012;53:1113-9.

14. Brøsen K, de Morais SM, Meyer UA, Goldstein JA. A multifamily study on the relationship between CYP2C19 genotype and s-mephenytoin oxidation phenotype. Pharmacogenetics. 1995:5:312-7.

15. de Morais SM, Goldstein JA, Xie HG, Huang SL, Lu YQ, Xia H, et al. Genetic analysis of the S-mephenytoin polymorphism in a Chinese population. Clin Pharmacol Ther. 1995;58:404-11.

16. Herrera-González S, Martínez-Treviño DA, Aguirre-Garza M, Gómez-Silva M, Barrera-Saldaña HA, León-Cachón RBR, et al. Effect of AGTR1 and BDKRB2 gene polymorphisms on atorvastatin metabolism in a Mexican population. Biomed Rep. 2017;7:579-84

17. Kuliczkowski W, Witkowski A, Polonski L, Watala C, Filipiak K, Budaj $A$, et al. Interindividual variability in the response to oral antiplatelet drugs: a position paper of the working group on antiplatelet drugs resistance appointed by the section of cardiovascular interventions of the polish cardiac society, endorsed by the working group on thrombosis of the European Society of Cardiology. Eur Heart J. 2009; 30:426-35.

18. Paniccia R, Priora R, Liotta AA, Abbate R. Platelet function tests: a comparative review. Vasc Health Risk Manag. 2015;11:133-48. 